\title{
Acute Toxicity of Experimental Fertilizers Made of Spent Coffee Grounds
}

\author{
Tomasz Ciesielczuk $^{1} \cdot$ Czesława Rosik-Dulewska $^{2} \cdot$ Joanna Poluszyńska $^{3}$ • \\ Daria Miłek $^{1} \cdot$ Agnieszka Szewczyk $^{3} \cdot$ Irena Sławińska $^{3}$
}

Received: 29 September 2016 / Accepted: 29 May 2017 / Published online: 1 June 2017

(C) The Author(s) 2017. This article is an open access publication

\begin{abstract}
Sustainable agriculture places new demands on agricultural practice and, in particular, plant protection treatments and fertilization. Therefore, an increase in demand for organic fertilizers of good quality is expected. In particular, the organic matter contained in the waste of the food industry or generated in households, in the absence of contamination, can be used for the production of "fertilizer", which could be used in organic crop production. The paper presents basic characteristics of tested mixtures and the results of testing for acute toxicity of the mixture made from spent coffee grounds (SCG) modified with ash arising from the low-temperature combustion of biomass or magnesium sulphate and blood meal. The plant tests were conducted on: mustard (Synapis alba L.), wheat (Triticum sp. L.), cucumber (Cucumis sativus L.) and garden cress (Lepidium sativum L.).Toxicity tests were carried out using a standard $72 \mathrm{~h}$ procedure using the Phytotoxkit microbiotest platelet involving fertilizer 2.5, 5 and $10 \%(\mathrm{v} / \mathrm{v})$. The
\end{abstract}

Tomasz Ciesielczuk

tciesielczuk@uni.opole.pl

Czesława Rosik-Dulewska

czeslawa.rosik-dulewska@ipis.zabrze.pl

Joanna Poluszyńska

j.poluszynska@icimb.pl

Daria Miłek

daria_milek@vp.pl

1 Department of Land Protection, Opole University, Oleska Str. 22, 45-052 Opole, Poland

2 Institute of Environmental Engineering of the Polish Academy of Sciences, Skłodowskiej-Curie Str. 34, 41-819 Zabrze, Poland

3 Institute of Ceramics and Building Materials, Oswiecimska Str. 21, 45-641 Opole, Poland results indicate the lack of toxic effect of the tested fertilization doses on the germination of the test plants, with the exception of cress. There was, however a strong inhibition of seedling growth during $72 \mathrm{~h}$ in samples containing $10 \%$ of the tested fertilizers, especially when they showed significant salinity and high $\mathrm{pH}$. The most sensitive species used for doses of fertilizer was cress, and the least sensitive was cucumber, for which there was a strong stimulation of root growth already at 5\% share of tested fertilizer in the substrate. EI shows particular individual character of tested species using fertilizer based on SCG. The inhibition of wheat roots elongation was observed even in $2.5 \%$ fertilizers fare.

Keywords Spent coffee grounds · SCG - Acute toxicity · Organic fertilizer $\cdot$ Sustainable agriculture

\section{Introduction}

Separate collection of biodegradable waste fractions, carried out at its source, enables not only to channel it to the process of composting or biogas production, but also to obtain high-quality fertilizer. This also applies to the waste solvent extractable materials generated after the preparation of beverages from coffee beans. These wastes are formed in large quantities due to the increasing consumption of this beverage [1]. The annual coffee consumption in Poland has been increasing and currently stands at $3 \mathrm{~kg}$ per capita, however this is a number several times lower than in the Scandinavian countries. In large part these wastes are directed to biodegradable fraction containers. In practice, however, the containers contain significant amounts of non-compostable waste and, even if a compost is produced, its quality will be low. 
This causes not only the loss of organic matter, but also the time and effort necessary to carry out the composting process. Spent coffee grounds (SCG) material includes a wide range of valuable organic compounds which contain, among others, tannic acid, cellulose, hemicellulose, lipids, organic acids and polyphenols and therefore it is used for the production of biochar, for composting as a sorbent and for the preparation of biodiesel [2-4]. SCG has been also considered as valuable source of polyphenols and galactomannans for application in medicine, cosmetics and food industry [5]. Attempts were also made to produce alcohol from the SCG, but the process requires a significant energy input [6].

An alternative way to use SCG is their processing into fertilizer without costly and lengthy process of composting. In this way, organic matter unencumbered by pollution can be a valuable source of nutrients for organic farming, acting in support for the dissemination of the principles of sustainable agriculture. The quality of the resulting fertilizer is high and does not pose a threat with heavy metals transmitted into the food chain $[7,8]$. An additional advantage is that the production of these fertilizers is so simple that it is possible to process them inhouse with the guarantee of obtaining the highest quality product. Only because of the phytotoxic nature of SCG it is necessary to determine the maximum dose that will not adversely affect the vegetation [1]. On the other hand, data obtained after using pre-composted fresh SCG confirm better lettuce plants elements composition (compared with lower yield) after use of high doses of this substratus [2].

Fertilizers produced on the basis of SCG could be used in organic crops cultivation regulated by the European Commission Regulation No. 354/2014 of 8 April 2014 (amending and correcting Regulation (EC) No. 889/2008 and laying down detailed rules for the implementation of Council Regulation (EC) No. 834/2007) on organic production and labelling of organic products with regard to organic production, labelling and control. Currently, organic farming in Poland occupies an area of 580.7 thousand hectares, and the use of the proposed fertilizers on a wider scale could contribute to the increase of this area (Eurostat 2016).

The aim of the study was to determine the acute toxicity of fertilizer products based on spent coffee grounds, modified with the addition of ash formed during low-temperature burning of biomass and other organic and mineral additives. For the purpose of the study "tableted fertilizers" were dissected. It should be emphasized that the examined fertilizers are tested for the first time, and the data about the use of such prepared conditioners have not been described in the available international literature.

\section{Materials and Methods}

\section{Material}

The study was conducted on SCG generated after the preparation of coffee beverages (under pressure of 15 atmospheres) and the ash derived from the thermal conversion of oak biomass (wood with bark). Additional components of the experimental fertilizers were chemically pure magnesium sulphate (MS) (POCH company) and/or blood meal (BM) [9]. All components of experimental fertilizers were dried in $105^{\circ} \mathrm{C}$ prior to use.

After preliminary testing, for experimental purposes five series of tableted fertilizer were prepared: K0, K10, $\mathrm{K} 12$, K13 and K20, of varying composition and destination (Table 1).

The method of making a tablet fertilizer was particularly described by Ciesielczuk et al. [10].

Organic content was determined by weight after ignition at $600^{\circ} \mathrm{C}$ for $3 \mathrm{~h}$. The $\mathrm{pH}$ value was determined in $\mathrm{H}_{2} \mathrm{O}$ and in $1 \mathrm{M} \mathrm{KCl}$ using 1:10 solutions. The content of organic carbon, Kiejdahl nitrogen, hydrogen and sulphur was determined with the use of a CHNS Vario Macro Cube analyzer (Elementar). The phosphorus content was determined by titration after digestion with sulphuric acid. The content of sodium, potassium and calcium were determined in wet mineralisates with the FES method using the BWB XP device. The content of magnesium and heavy metals such as zinc, copper, lead, nickel, chromium, and cadmium were determined by an atomic absorption spectroscopy using the Thermo iCE 3500 device after microwave wet digestion with aqua regia in the Mars-X device.

In order to determine the initial release of nutrients, aqueous extract was made according to PN-Z-15009 (16 h shaking, $4 \mathrm{~h}$ rest, $2 \mathrm{~h}$ shaking, filtration). Furthermore $\mathrm{pH}$, an appropriate electrolytic conductivity (EC) with electrometric methods, the content of organic carbon and total nitrogen by detecting a non-dispersive infrared absorption (NDIR), after the mineralization of

Table 1 Mass proportions of components in fertilizer tablets in total dry state

\begin{tabular}{llllll}
\hline $\begin{array}{l}\text { Fertilizer } \\
\text { type }\end{array}$ & $\begin{array}{l}\text { Spent cof- } \\
\text { fee grounds } \\
\text { (SCG) }\end{array}$ & Ash (A) & $\begin{array}{l}\text { Mag- } \\
\text { nesium } \\
\text { sulphate } \\
\text { (MS) }\end{array}$ & $\begin{array}{l}\text { Blood } \\
\text { meal } \\
\text { (BM) }\end{array}$ & Gelatine \\
\hline K0 & 10 & 0 & 0 & 0 & 1 \\
K10 & 9 & 1 & 0 & 0 & 1 \\
K12 & 9 & 0.1 & 0.9 & 0 & 1 \\
K13 & 8 & 0.3 & 0.7 & 1 & 1 \\
K20 & 8 & 2 & 0 & 0 & 1 \\
\hline
\end{tabular}


the sample at a temperature of $850^{\circ} \mathrm{C}$ were determined in the extracts. The content of phosphate ion and nitrate was determined by IC, using the high performance ion chromatograph Metrohm 850 Professional IC AnCat - MCS, and potassium and calcium content was determined in wet mineralisates with the FES method using the BWB XP device.

The acute toxicity of the examined fertilizer was determined based on a plants germination test. It was made with: wheat Triticum sp. L. (T), ground cucumber Cucumis sativus L. var. 'Krak' (C), white mustard Synapis alba L. (S) and garden cress Lepidium sativum L. (L) Germination plates (Phytotoxkit microbiotest). The experimental tests included further grounding and sieving, through a sieve having a mesh of $1 \mathrm{~mm}$, of fertilizers $\mathrm{K} 0, \mathrm{~K} 10, \mathrm{~K} 12$, K13 and $\mathrm{K} 20$, which were mixed thoroughly with the peat-sand $(1 / 1 \mathrm{v} / \mathrm{v}$ d.m. $)$ substrate. The addition of fertilizer to the substrate was 2.5, 5 and $10 \%(\mathrm{v} / \mathrm{v})$. The prepared substrate was moistened with water (WZ) of $\mathrm{pH} 7.06$, EC $239 \mathrm{uS}$ $\mathrm{cm}^{-1}$, mineralization $180 \mathrm{mg} \mathrm{dm}^{-3}$. Peat-sand mixture was used as control sample.

Each plate was seeded with ten seeds of the test plants, which were then incubated in the dark at a temperature of $25 \pm 0.5^{\circ} \mathrm{C}$ for $72 \mathrm{~h}$ [11]. After this time, photographs of the test plates were taken and root length was determined using the ImageTool ${ }^{\circledR}$ programme. The germination rate for a series of experimental and control groups was calculated from the equation $\mathrm{GI}=\mathrm{G}_{\mathrm{e}} / \mathrm{G}_{\mathrm{k}} \times 100$, where GE and $\mathrm{Gk}$ are the number of germinated seeds in the experimental and control series, and the elongation rate was calculated from the equation $\mathrm{EI}=\mathrm{L}_{\mathrm{e}} / \mathrm{L}_{\mathrm{k}} \times 100$, where Le and $\mathrm{Lk}$ are the length of test plants in mm. It was assumed that the lack of difference in the range from 90 to $110 \%$ is considered as no effect of fertilization. The one-way analysis of variance (ANOVA) was carried out using the statistical package PQStat. An analysis of variance was performed separately for each species of test plants.

\section{Results and Discussion}

\section{Characteristics of Tableted Fertilizers}

The examined fertilizers had a $\mathrm{pH}$ ranging from 5.92 to $9.15\left(\mathrm{pH}_{\mathrm{KCl}}\right)$ and from 5.61 to $8.77\left(\mathrm{pH}_{\mathrm{H} 2 \mathrm{O}}\right)$ (Table 2). The results obtained for the SCG are confirmed by other authors [12]. Our own results indicate that even the series of a tablet fertilizer without the addition of ash from biomass are not highly acidifying fertilizers. The $\mathrm{K} 0$ and $\mathrm{K} 12$ series exhibit a slight acidifying effect, K10 and K13 can be considered as neutral fertilizers; only the K20 series are de-acidifying. It should be noted that some other results for $\mathrm{pH}\left(\mathrm{pH}_{\mathrm{H} 2 \mathrm{O}}\right)$ were obtained in the case of aqueous extract of the examined fertilizers, for which the results are presented later in this work. This is due to the different methodology for the determination of $\mathrm{pH}$ in fertilizers and in aqueous extracts. From the soil salination point of view, very disturbing is the high value of electrolytic conductivity in the K12 and K13 series (respectively 5.18 and $4.23 \mathrm{mS} / \mathrm{cm}$ ). Even though the breakdown of fertilizer delivered in the form of tablets will be very slow (even without the cellulose and collagen coating), such a significant salinity (occurring even locally) can be dangerous for plants. Other fertilizers have a lower salinity $(0.89-2.60 \mathrm{mS} / \mathrm{cm})$, and therefore it is not expected that they will exhibit a toxic effects on seedling growth.

Table 2 Basic characteristics of SCG and investigated fertilizers $(n=3)$

\begin{tabular}{lcccccc}
\hline & $\mathrm{SCG}$ & $\mathrm{K} 0$ & $\mathrm{~K} 10$ & $\mathrm{~K} 12$ & $\mathrm{~K} 13$ & $\mathrm{~K} 20$ \\
\hline Reaction $\left(\mathrm{pH}_{\mathrm{KCl}}\right)$ & $5.96(0.06)$ & $5.92(0.18)$ & $8.23(0.24)$ & $6.11(0.11)$ & $7.17(0.28)$ & $9.15(0.16)$ \\
Reaction $\left(\mathrm{pH}_{\mathrm{H} 2 \mathrm{O}}\right)$ & $5.64(0.05)$ & $5.61(0.21)$ & $7.15(0.26)$ & $5.89(0.15)$ & $6.39(0.14)$ & $8.77(0.14)$ \\
$\mathrm{EC}(\mathrm{mS} / \mathrm{cm})$ & $0.95(0.11)$ & $0.89(0.06)$ & $1.97(0.13)$ & $5.18(0.54)$ & $4.23(0.10)$ & $2.60(0.12)$ \\
Organic substances $(\%)$ & $98.5(0.03)$ & $97.9(0.06)$ & $89.5(0.54)$ & $93.6(0.63)$ & $92.7(0.06)$ & $80.8(0.8)$ \\
$\mathrm{TOC}(\%)$ & $53.3(3.57)$ & $52.05(3.49)$ & $46.6(3.12)$ & $45.9(3.08)$ & $45.15(3.03)$ & $43.4(2.91)$ \\
$\left.\mathrm{N}_{\mathrm{Kiejd}} . \%\right)$ & $2.45(0.38)$ & $3.83(0.59)$ & $3.33(0.52)$ & $3.32(0.51)$ & $4.18(0.65)$ & $3.09(0.48)$ \\
$\mathrm{C} / \mathrm{N}$ & 21.75 & 13.59 & 14.00 & 13.82 & 10.80 & 14.04 \\
$\mathrm{CaO}(\mathrm{g} / \mathrm{kg} \mathrm{dw})$ & $0.57(0.12)$ & $1.20(0.30)$ & $14.3(1.22)$ & $4.71(0.17)$ & $10.3(1.27)$ & $29.7(0.86)$ \\
$\mathrm{MgO}(\mathrm{g} / \mathrm{kg} \mathrm{dw})$ & $7.24(1.5)$ & $7.54(2.87)$ & $7.71(0.08)$ & $157.9(12.5)$ & $86.6(4.2)$ & $7.73(1.56)$ \\
$\mathrm{S}(\%)$ & $0.132(0.022)$ & $0.135(0.022)$ & $0.234(0.038)$ & $2.47(0.405)$ & $2.19(0.359)$ & $0.334(0.055)$ \\
$\mathrm{H}(\%)$ & $7.78(1.43)$ & $7.88(1.45)$ & $6.75(1.24)$ & $7.24(1.33)$ & $7.09(1.30)$ & $6.33(1.16)$ \\
$\mathrm{Na}_{2} \mathrm{O}(\mathrm{g} / \mathrm{kg} \mathrm{dw})$ & $1.30(0.16)$ & $0.60(0.004)$ & $0.47(0.004)$ & $0.86(0.03)$ & $0.94(0.06)$ & $0.99(0.04)$ \\
$\mathrm{K}_{2} \mathrm{O}(\mathrm{g} / \mathrm{kg} \mathrm{dw})$ & $3.05(0.18)$ & $5.05(0.33)$ & $9.92(0.22)$ & $4.48(0.12)$ & $5.28(0.26)$ & $23.8(0.22)$ \\
$\mathrm{P}_{2} \mathrm{O}_{5}(\mathrm{~g} / \mathrm{kg} \mathrm{dw})$ & $5.27(0.01)$ & $3.78(0.16)$ & $7.22(0.09)$ & $3.78(0.21)$ & $7.99(0.11)$ & $9.28(0.23)$ \\
\hline
\end{tabular}

$\mathrm{SD}$ value in brackets 
The tested fertilizers, due to the large share of SCG (over $72 \%$ ), are characterized by a very high organic content (organic carbon content exceed 50\% for the SCG and $\mathrm{K} 0$, and exceeding $40 \%$ for the remaining fertilizer series), which is unprecedented in other types of natural organic fertilizers, except good quality manure or slurry. The composition of organic matter includes mainly polysaccharides, proteins and fats which guarantee the slow release of nutrients from decaying organic matter [13, 14]. The content of fat in SCG is high, with an average value of $15 \%$ [1], but our own research shows the significant influence of the method of coffee making on the content of fat in the SCG.

The nitrogen content in the tested fertilizer series is high and exceeds 3\%. An exception is SCG without addition of other compounds, where the nitrogen content is $2.45 \%$ and the $\mathrm{C} / \mathrm{N}$ ratio is 21.7 , which is also confirmed by other authors $[1,13]$. The established content is comparable to the amount of nitrogen in liquid manure, and higher than those recorded in composts and manure [14] and in samples of SCG given by other authors [4].

The calcium content correlates strongly (corr. coef 0.98 ) with the participation of ash from the biomass. The K20 series has nearly 25 times more of this element than K0 with no ash added. A similar correlation coefficient $(0.97)$ was reported for potassium content which, like calcium, is supplied with ash. It should be emphasized that both these elements are present in a form easily absorbable for plants $[15,16]$.

The magnesium content is particularly high for the K12 series, where the additive of magnesium sulphate was used (Table 1). In the remaining samples, the $\mathrm{Mg}$ content is lower, but the addition of $\mathrm{BM}$ also raises the magnesium content by more than $2 \times$ as compared to the fertilizer without this addition.

Minor differences in sodium, potassium and phosphorus is comparable to the values obtained in earlier studies [10].

\section{Aqueous Extracts of the Tested Fertilizers}

Aqueous extracts obtained from $\mathrm{K} 0$ and $\mathrm{K} 12$ have an acidifying reaction (Table 3), and the fertilizer stabilizing $\mathrm{pH}$ is K10. Material K20, from which the alkaline extract was obtained, has $\mathrm{pH}$ similar to the one obtained from the water extracts derived from mixtures of sludge and ash from coal combustion [8]. This may be particularly important in the case of acid soils, or soils susceptible to acidification, which require regular liming. A worrying phenomenon is the strong salinity of the solution, particularly pronounced in the case of the K12 and K13 series. In both cases it is the effect of the addition of a significant amount of magnesium sulphate (respectively 8.2 and $6.4 \%$ by weight) to supplement the deficiency of this nutrient in the soil. The sensitivity of plants to salinity depends on the specific species, but research carried out for cucumbers show a toxic effect only at the level of conductivity of 6-8 $\mathrm{mS} / \mathrm{cm}$ [17].

Particularly important is the release of particular forms of nitrogen into the soil solution. In the obtained extracts from fertilizers having a small share of ash (K0, K12 and $\mathrm{K} 13$ ), dominates the ammonium form, which is greater than the concentration of nitrates in K0 by almost 12 times. In a series of fertilizer with higher amounts of ash (K10) this advantage is small, and the ratio of $\mathrm{NH}_{4}{ }^{+}$to $\mathrm{NO}_{3}{ }^{-}$is $1.4: 1$. On the other hand, in the case of the K20 series the nitrate form dominates. Definitively higher amounts of ammonium ions exceeding $230 \mathrm{mg} / \mathrm{dm}^{3}$ were found in water extracts
Table 3 Characteristic of water extract of investigated fertilizer tablets

\begin{tabular}{lcccccc}
\hline & SCG & $\mathrm{K} 0$ & $\mathrm{~K} 10$ & $\mathrm{~K} 12$ & $\mathrm{~K} 13$ & $\mathrm{~K} 20$ \\
\hline Reaction $(\mathrm{pH})$ & 5.70 & 5.88 & 6.90 & 5.69 & 7.24 & 8.69 \\
$\mathrm{EC}(\mathrm{mS} / \mathrm{cm})$ & 1.12 & 0.62 & 1.84 & 5.85 & 3.32 & 2.45 \\
$\mathrm{~N}_{\mathrm{Kiejd}}\left(\mathrm{mg} / \mathrm{dm}^{3}\right)$ & $152.7(1.27)$ & $165.1(2.60)$ & $140.6(1.57)$ & $320.0(1.33)$ & $122.8(0.54)$ & $110.0(0.39)$ \\
$\mathrm{NH}_{4}^{+}\left(\mathrm{mg} / \mathrm{dm}^{3}\right)$ & $<0.05$ & $4.37(0.78)$ & $3.09(0.55)$ & $7.82(1.4)$ & $8.16(1.5)$ & $0.115(0.02)$ \\
$\mathrm{NO}_{2}^{-}\left(\mathrm{mg} / \mathrm{dm}^{3}\right)$ & $0.900(0.14)$ & $0.221(0.033)$ & $0.658(0.099)$ & $1.49(0.23)$ & $1.92(0.3)$ & $1.31(0.20)$ \\
$\mathrm{NO}_{3}^{-}\left(\mathrm{mg} / \mathrm{dm}^{3}\right)$ & $0.204(0.02)$ & $0.368(0.028)$ & $2.23(0.17)$ & $1.82(0.14)$ & $2.26(0.2)$ & $2.91(0.2)$ \\
$\mathrm{PO}_{4}^{-3}\left(\mathrm{mg} / \mathrm{dm}^{3}\right)$ & $87.7(18)$ & $49.3(9.9)$ & $19.0(3.8)$ & $80.6(16)$ & $30.5(6)$ & $2.83(0.6)$ \\
$\mathrm{SO}_{4}^{-2}\left(\mathrm{mg} / \mathrm{dm}^{3}\right)$ & $9.99(2)$ & $49.5(9.9)$ & $166(33)$ & 5411 & $2555(504)$ & $407(80)$ \\
$\mathrm{Na}^{+}\left(\mathrm{mg} / \mathrm{dm}^{3}\right)$ & $98.4(11)$ & $46.3(5.3)$ & $29.8(2.3)$ & $15.8(1.8)$ & $58.6(7)$ & $49.9(6)$ \\
$\mathrm{K}^{+}\left(\mathrm{mg} / \mathrm{dm}^{3}\right)$ & $405(25)$ & $146(9.1)$ & $602(38)$ & $412(26)$ & $325(20)$ & $1105(69)$ \\
$\mathrm{Ca}^{2+}\left(\mathrm{mg} / \mathrm{dm}^{3}\right)$ & $82.1(15)$ & $14.6(2.7)$ & $50.9(9.3)$ & $114(19)$ & $138(25)$ & $158(29)$ \\
$\mathrm{Mg}^{2+}\left(\mathrm{mg} / \mathrm{dm}^{3}\right)$ & $79.5(9)$ & $9.37(1.1)$ & $38.7(4.5)$ & $1280(146)$ & $532(62)$ & $9.72(1.1)$ \\
$\mathrm{Cl}^{-}\left(\mathrm{mg} / \mathrm{dm}^{3}\right)$ & $4.15(0.3)$ & $10.1(0.78)$ & $15.5(1.2)$ & $3.18(0.25)$ & $24.7(2)$ & $17.0(1)$ \\
$\mathrm{TOC}\left(\mathrm{g} / \mathrm{dm}^{3}\right)$ & $3.12(0.39)$ & $1.72(0.63)$ & $1.75(0.53)$ & $3.02(1.32)$ & $1.18(0.34)$ & $1.49(0.38)$ \\
\hline
\end{tabular}

SD value in brackets

*In this case a ground SCG were used (not in tablet form) 
obtained from mixtures of sludge and ash from coal combustion, which could pose a threat to crop seedlings [8].

Rich in easily soluble phosphorus compounds are the SCG fertilizers $\left(87.7 \mathrm{mg} / \mathrm{dm}^{3}\right)$ and $\mathrm{K} 12\left(80.6 \mathrm{mg} / \mathrm{dm}^{3}\right)$. At a pH higher than 6-7, phosphorus in the soil can be immobilized, which would be extremely detrimental to the efficiency of fertilization as it is a necessary component in the life of plants. A small amount of phosphorus released into solution is a characteristic feature of K20 fertilizer as it is as much as 30 times lower than in the case of SCG.

The high content of sulphate ions in the water extracts from $\mathrm{K} 12$ and $\mathrm{K} 13$ fertilizers is due to the addition of magnesium sulphate. The SCG, in turn, has a relatively low content of these ions.

The content of calcium in the water extracts from fertilizers is different due to ash content. The amount of calcium in the soil from an agricultural perspective would be very favourable because, when causing coagulation of the soil colloids, it positively affects the creation of lumpy structure of the soil and increases the $\mathrm{pH}$.

A very high content of easily soluble potassium compounds were determined in K20 fertilizer $\left(1105 \mathrm{mg} / \mathrm{dm}^{3}\right)$ and $\mathrm{K} 10\left(602 \mathrm{mg} / \mathrm{dm}^{3}\right)$, which is associated with a substantial share of ash. Large amounts of potassium are not an obstacle for plants because they can retrieve it, even in excessive amounts - it is so-called "luxury uptake". Potassium increases the nurture of plants, stimulates the growth of new ones, and improves resistance to all kinds of diseases.

\section{Acute Toxicity}

The SCG as raw plant waste is characterized by a strong phytotoxic impact, associated inter alia with caffeine, tannins and polyphenols content [1, 18], but other authors [19] have shown no direct relationship between $\mathrm{pH}, \mathrm{EC}$ and the content of polyphenols, and the toxic effect on plants, suggesting interaction with other compounds e.g., fatty acids. The high level of toxicity of SCG was not confirmed in neither pot experiment nor field trials using lettuce, which in combination with high levels of antioxidants gives the possibility for extensive use of this fertilizer in horticultural practice [2]. The amounts of tested fertilizers were relatively high (equivalent to doses of manure, respectively $6.25,12.5$ and $25 \mathrm{dm}^{3} / \mathrm{m}^{2}$ with plowing to a depth of $25 \mathrm{~cm}$, or 50,100 and $200 \mathrm{Mg}$ of manure per ha), and additionally the powdery form in which they were applied ensures a maximum impact of the fertilizer on the soil solution and germinating plants as a result of the huge contact area of fertilizer and soil solution. Under the conditions of use of a fertilizer in the form of tablets coated with a membrane made of cellulose and collagen, its impact will be much slower. Germination rates varied for each test plant
Table 4 Germination index (GI) of tested plants species at 2.5; 5 and $10 \%$ fertilizers fare

\begin{tabular}{lllll}
\hline & Lepidium & Triticum & Cucumis & Synapis \\
\hline SCG & $100 / 129 / 80$ & $111 / 100 / 90$ & $100 / 100 / 100$ & $80 / 100 / 100$ \\
K0 & $114 / 129 / 80$ & $111 / 100 / 100$ & $100 / 100 / 111$ & $100 / 100 / 111$ \\
K10 & $114 / 100 / 40$ & $111 / 100 / 100$ & $100 / 100 / 100$ & $100 / 100 / 100$ \\
K12 & $128 / 143 / 70$ & $111 / 90 / 100$ & $100 / 100 / 111$ & $90 / 100 / 89$ \\
K13 & $100 / 143 / 90$ & $111 / 100 / 100$ & $100 / 100 / 111$ & $90 / 100 / 111$ \\
K20 & $114 / 100 / 90$ & $111 / 100 / 100$ & $100 / 100 / 111$ & $100 / 100 / 111$ \\
\hline
\end{tabular}

species and series of fertilizer (Table 4). The lowest rates were recorded for the germination of cress (Lepidium).

This species (Lepidium) showed a high sensitivity, particularly in the trials with $\mathrm{K} 10$ and K12 fertilizers. The lowest amount of germinated seeds of the test species was observed with a $10 \%$ additive of $\mathrm{K} 10$ fertilizer $(\mathrm{GI}=40 \%)$ and $\mathrm{K} 12(\mathrm{GI}=70 \%)$, which in the case of $\mathrm{K} 10$ is defined as a significant inhibition of germination [20].

Other species tested (T, C, and S) germinated well and reported no direct correlation between the GI index and the applied level of fertilization. A significant reduction in germination was expected for samples with the addition of SCG because, when using this fertilizer as a substrate in the preliminary experiments carried out, the Lepidium seeds did not germinate. What was also expected were smaller quantities of germinated seeds in the case of a substrate containing a series of $\mathrm{K} 12$ fertilizer because of its high conductivity, but in practice a decrease of germinated seeds was observed only in the case of Lepidium. Other species of plants germinated well, even at maximum doses of the fertilizer.

\section{Elongation Indicators (EI)}

In the case of the $\mathrm{L}$ plant there was a significant spread of root length measured in the $72 \mathrm{~h}$ of the experiment (Table 5). A particularly high dispersion was obtained in the control series, both within the group and between groups. Particularly surprising is the strong inhibition of the growth of roots in the case of a 5\% addition of neutral K10 series fertilizer. These results are comparable with those obtained for this species (L), and for a $10 \%$ additive in the case of the highly salinating K12 and K13 series. In a similar study, the species showed no decline in the germination until the EC 2.4 at $\mathrm{pH} 4.2$, but in these conditions a strong inhibition of root elongation in the $72 \mathrm{~h}$ of the test was observed [19].

For the T species, very good results were obtained from the addition of the series of fertilizers in quantities of $2.5 \%$ (Table 4). The addition of $5 \%$ of SCG caused stimulation of root growth. For other test series, fertilizer additive in the 
Table 5 Longitude of roots of tested plants with 2.5; 5 and $10 \%$ fertilizers fare $(\%)(\mathrm{n}=10)$

\begin{tabular}{|c|c|c|c|c|c|c|c|}
\hline & Control* & SCG & K0 & K10 & K12 & K13 & K20 \\
\hline \multicolumn{8}{|c|}{ Lepidium (Lepidium sativum L.) } \\
\hline $2.5 \%$ & $5.4(2.1)$ & $6.1(1.4)$ & $4.3(0.5)$ & $3.6(0.8)$ & $3.9(1.9)$ & $3.6(1.0)$ & $3.8(1.9)$ \\
\hline $5 \%$ & $4.5(2.0)$ & $3.6(1.0)$ & $2.4(0.9)$ & $1.6(0.3)$ & $4.2(0.9)$ & $2.9(0.8)$ & $4.3(0.9)$ \\
\hline $10 \%$ & $3.2(0.9)$ & $4.5(1.0)$ & $1.5(0.8)$ & $2.1(0.2)$ & $1.4(0.6)$ & $1.3(0.3)$ & $2.5(0.6)$ \\
\hline \multicolumn{8}{|c|}{ Triticum (Triticum sp. L.) } \\
\hline $2.5 \%$ & $5.2(1.5)$ & $4.7(1.6)$ & $4.8(1.0)$ & $3.7(1.6)$ & $4.8(1.7)$ & $4.8(1.6)$ & $4.8(0.8)$ \\
\hline $5 \%$ & $4.4(1.2)$ & $5.3(1.9)$ & $4.0(1.6)$ & $2.2(1.2)$ & $1.9(0.9)$ & $1.7(0.5)$ & $1.9(1.3)$ \\
\hline $10 \%$ & $6.1(1.5)$ & $5.7(1.7)$ & $3.3(1.3)$ & $2.9(0.8)$ & $2.6(0.9)$ & $1.7(0.4)$ & $2.2(1.0)$ \\
\hline \multicolumn{8}{|c|}{ Cucumis (Cucumis dativus L.) } \\
\hline $2.5 \%$ & $6.3(1.3)$ & $6.6(1.7)$ & $6.4(0.7)$ & $6.5(0.5)$ & $5.6(1.4)$ & $6.0(0.6)$ & $5.4(1.9)$ \\
\hline $5 \%$ & $6.1(2.2)$ & $7.1(0.6)$ & $4.5(0.6)$ & $4.8(0.2)$ & $5.1(0.3)$ & $5.0(0.6)$ & $6.0(0.5)$ \\
\hline $10 \%$ & $7.0(1.1)$ & $7.5(1.0)$ & $5.0(0.8)$ & $4.2(0.5)$ & $4.1(0.5)$ & $3.9(0.5)$ & $3.6(0.9)$ \\
\hline \multicolumn{8}{|c|}{ Synapis (Synapis alba L.) } \\
\hline $2.5 \%$ & $4.7(2.6)$ & $5.5(2.1)$ & $4.8(2.1)$ & $5.9(1.4)$ & $6.0(2.3)$ & $5.4(2.1)$ & $6.8(1.4)$ \\
\hline $5 \%$ & $2.9(0.9)$ & $5.3(2.6)$ & $2.3(0.6)$ & $3.1(0.6)$ & $4.8(0.7)$ & $5.2(1.3)$ & $5.1(2.0)$ \\
\hline $10 \%$ & $4.4(2.6)$ & $6.3(2.1)$ & $2.8(0.6)$ & $2.1(0.7)$ & $3.0(1.0)$ & $2.1(0.9)$ & $2.9(1.4)$ \\
\hline
\end{tabular}

SD value in brackets

*The results of control series (base substrate without fertilizer additives) were obtained separately for each experimental series amount of 5 and $10 \%$ reduced the rate of root growth, but the differences were relatively small.

In case of $\mathrm{C}$ seedlings, the increase in the share of SCG in the substrate resulted in increasingly stronger root growth and length. The addition of the K0, K10 and K13 fertilizer series in the amount of $2.5 \%$ caused neither the stimulation nor the inhibition of root length, but with an increased dose, a decrease in root length was recorded in each case of addition of the tested fertilizers series.

Interesting results were obtained for the $S$ species (Table 5), where the root growth was inhibited only after application of $10 \%$ of the fertilizer to the substrate; the addition of $5 \%$ resulted in a strong stimulation of growth. In experiments with pure SCG conducted on lettuce a low yield were obtained only for very high doses of SCG (20 and $30 \%$ pre-composted with soil fresh SCG) [2].

\section{Statistical Analysis}

One way analysis of variance (ANOVA) showed a statistical difference between the obtained average. Although the differences occurred-both statistically significant and highly significant-between the experimental groups, in which the substrate was modified with additives of the studied series of fertilizer, in this paper only the statistical differences that occurred between the control group and experimental groups within a species and at a given level of fertilization are presented. In the case of the Lepidium species, the strongest inhibition was observed for substrates with a $10 \%$ addition of $\mathrm{K} 10$ and K12 fertilizers-respectively
50.2 and $55.7 \%$. Only in the tests with a $2.5 \%$ addition of fertilizers did no highly significant statistical differences $(\alpha=0.01$ ) occur between the control and fertilized groups, while in the other tests (for substrates with a 5 and $10 \%$ addition of fertilizer) for this species, such differences occurred (Table 6). An even more significant influence of the used fertilizer doses was recorded for the Triticum species where, in the case of K13 and K20 fertilizers, inhibition amounted to 71.2 and $63.6 \%$ respectively. In this case a highly significant difference was observed only for fertilizer added in the amounts of 5 and $10 \%$. A similar sensitivity was demonstrated for plants of the Cucumis species, wherein the strongest inhibition of root growth was observed at the level of 44.1 and $47.5 \%$ respectively for the K13 and K20 series, and highly significant differences for the tests with a $10 \%$ dose were reported for the same series of fertilizers as for Triticum. Similarly strong growth inhibition of Lepidium seedlings was obtained on substrates with a $6 \%$ addition of sewage sludge and composts from these deposits [21].

The least sensitive species is Synapis for which the addition of fertilizers (except K0) in the amount of $2.5 \%$ resulted in stimulation of root growth by $44 \%$; however, statistically significant differences $(\alpha=0.05)$ for this level of fertilization were observed only between the control group and the K20 series. Two-time quantitative growth of additives of the SCG, K12, K13 and K20 series to 5\% caused further stimulation of root growth, which in the case of the SCG, K13 and K20 was almost twice as long as the control ones. At that dose of fertilizer, a high statistical significance 
Table 6 Elongation index (EI) of roots and statistical differences (according to control samples) for plots with $2.5 ; 5$ and $10 \%$ fertilizers fare $(\%)$ $(\mathrm{n}=10)$

\begin{tabular}{lllllllll}
\hline & $\begin{array}{l}\text { Fertilizer fare } \\
(\mathrm{v} / \mathrm{v})(\%)\end{array}$ & Control* & SCG & K0 & K10 & K12 & K13 & K20 \\
\hline Lepidium & 2.5 & $100 \mathrm{a}$ & 113.1 & 78.6 & $65.6 \mathrm{~b}$ & 72.5 & $65.7 \mathrm{~b}$ & $70.3 \mathrm{~b}$ \\
& 5 & $100 \mathrm{~A}$ & 81.4 & $53.8 \mathrm{~B}$ & $35.5 \mathrm{~B}$ & 93.8 & $64.5 \mathrm{~B}$ & 96.7 \\
& 10 & $100 \mathrm{Aa}$ & $140.2 \mathrm{~B}$ & $53.0 \mathrm{~B}$ & $73.1 \mathrm{~b}$ & $49.8 \mathrm{~B}$ & $44.3 \mathrm{~B}$ & $86.8 \mathrm{~b}$ \\
Triticum & 2.5 & $100 \mathrm{a}$ & 91.4 & 92.7 & $71.9 \mathrm{~b}$ & 92.1 & 92.0 & 92.6 \\
& 5 & $100 \mathrm{~A}$ & 118.4 & 90.3 & $48.5 \mathrm{~B}$ & $42.9 \mathrm{~B}$ & $37.5 \mathrm{~B}$ & $41.7 \mathrm{~B}$ \\
& 10 & $100 \mathrm{~A}$ & 93.3 & $54.8 \mathrm{~B}$ & $48.0 \mathrm{~B}$ & $42.0 \mathrm{~B}$ & $28.8 \mathrm{~B}$ & $36.4 \mathrm{~B}$ \\
Cucumis & 2.5 & 100 & 105.0 & 101.6 & 102.9 & 89.2 & 94.5 & 85.0 \\
& 5 & $100 \mathrm{Aa}$ & $116.5 \mathrm{~b}$ & $74.4 \mathrm{~B}$ & $78.3 \mathrm{~B}$ & $83.2 \mathrm{~b}$ & $81.8 \mathrm{~b}$ & 97.7 \\
& 10 & $100 \mathrm{~A}$ & 108.3 & $71.4 \mathrm{~B}$ & $60.5 \mathrm{~B}$ & $58.5 \mathrm{~B}$ & $55.9 \mathrm{~B}$ & $52.5 \mathrm{~B}$ \\
Synapis & 2.5 & $100 \mathrm{a}$ & 115.7 & 101.0 & 124.0 & 126.0 & 113.4 & $144.0 \mathrm{~b}$ \\
& 5 & $100 \mathrm{~A}$ & $184.8 \mathrm{~B}$ & 80.0 & 108.5 & $166.5 \mathrm{~B}$ & $180.9 \mathrm{~B}$ & $177.3 \mathrm{~B}$ \\
& 10 & $100 \mathrm{Aa}$ & $145.0 \mathrm{~B}$ & $63.3 \mathrm{~b}$ & $48.2 \mathrm{~B}$ & 67.7 & $48.3 \mathrm{~B}$ & $65.6 \mathrm{~b}$ \\
\hline
\end{tabular}

*The results of control series (base substrate without fertilizer additives) were obtained separately for each experimental series

A, B $-\alpha=0.01 ; \mathrm{a}, \mathrm{b}-\alpha=0.05$ was recorded for the differences between the control and the series with additions of SCG, K12, K13 and K20. In this case there is an "acute stimulation" of root growth. An inhibiting reaction was observed only in the case of a $10 \%$ addition of fertilizers, but the addition of SCG continued to support the development of Synapis seedlings; however, at this level of fertilizing with $\mathrm{K} 12$ additive there were no significant differences.

To sum up, described experiments show that GI parameters do not have real influence of tested fertilizers on plants seedlings. Only combination of GI and EI indexes can be a good characteristic of first 3 days of plant growth on fertilized substratum.

\section{Conclusions}

Tests of germination and growth of test plant roots in the first 3 days after sowing have become increasingly important indicators of phytotoxicity. This study shows varied levels of acute toxicity of tested fertilizers in relation to test plant species. The highest investigated level of fertilizers in a powdered form, based on SCG with additives (especially K10 and K12), inhibited the germination of plants of the Lepidium species, without having such an effect on other tested plants. Fertilization with such high doses of fertilizers also resulted in inhibition of root growth of the test plants. The strongest inhibitory interaction was observed when using the highest applied dose of the K13 and K20 fertilizer series for seedlings of Triticum and Cucumis. However, in the case of Lepidium such an impact was recorded for the K12 and K13 series, and the Synapis plants species was inhibited the most by a $10 \%$ addition of $\mathrm{K} 10$ and K13 fertilizers. Surprisingly, a 5\% additive of K12, K13 and K20 fertilizers and the addition of SCG strongly stimulated the development of the species' roots, therefore the best mixtures seems to be $\mathrm{K} 12$ and $\mathrm{K} 13$, but used in low fares. The recorded differences that were statistically significant and highly significant confirm both inhibition and stimulation of the development of the roots of the test plants by the fertilizer additives.

In summary, these results indicate the possibility of using SCG and ash from biomass as the main components of cheap fertilizers that may be used in organic crop cultivation, contributing to the use of organic compounds in the tested waste and mineral compounds contained in the ash from biomass. It is worth emphasizing that the production of tableted fertilizer can be carried out by persons engaged in gardening as a hobby and also, that by changing the participation of both the above-mentioned basic ingredients, it is possible to adjust the $\mathrm{pH}$ of the produced fertilizer depending on momentary needs.

Open Access This article is distributed under the terms of the Creative Commons Attribution 4.0 International License (http:// creativecommons.org/licenses/by/4.0/), which permits unrestricted use, distribution, and reproduction in any medium, provided you give appropriate credit to the original author(s) and the source, provide a link to the Creative Commons license, and indicate if changes were made.

\section{References}

1. Mussatto, S.I., Machado, E.M.S., Martins, S., Teixeira, J.A.: Production, composition, and application of coffee and its industrial residues. Food Bioprocess. Technol. (2011). doi:10.1007/ s11947-011-0565-z. 
2. Cruz, R., Mendes, E., Torrinha, A., Morais, S., Pereira, J.A., Baptista, P., Casal, S.: Revalorization of spent coffee residues by a direct agronomic approach. Food Res. Int. (2015). doi:10.1016/j.foodres.2014.11.018

3. Caetano, N.S., Silva, V.M.F., Melo, A.C., Martins, A.A., Mata, T.M.: Spent coffee grounds for biodiesel production and other applications. Clean Technol. Environ. Policy (2014). doi:10.1007/s10098-014-0773-0

4. Pujol, D., Liu, C., Gominho, J., Olivella, M.À., Fiol, N., Villaescusa, I., Pereira, H.: The chemical composition of exhausted coffee waste. Ind. Crops Prod. (2013). doi:10.1016/j. indcrop.2013.07.056

5. Campos-Vega, R., Guadalupe Loarca-Pina, G., Vergara-Castaneda, H.A., Oomah, B.D.: Spent coffee grounds: A review on current research and future prospects. Trends Food Sci. Technol. (2015). doi:10.1016/j.tifs.2015.04.012

6. Sampaio, A., Dragone, G., Vilanova, M., Oliveira, J.M., Teixeira, J.A., Mussatto, S.I.: Production, chemical characterization, and sensory profile of a novel spirit elaborated from spent coffee grodns. LWT Food Sci. Technol. 54, 557-563 (2013). doi:10.1016/j.1wt.2013.05.042

7. Lopes, C., Herva, M., Franco-Uría, A., Roca, E.: Inventory of heavy metal content in organic waste applied as fertilizer in agriculture: evaluating the risk of transfer into the food chain. Environ. Sci. Pollut. Res. (2011). doi:10.1007/s11356-011-0444-1

8. Rosik-Dulewska, C., Głowala, K., Karwaczyńska, U., Szydło, E.: The mobility of chosen pollutants from ash-sludge mixtures. Polish J. Environ. Stud. 15(6), 895-904 (2006)

9. Roy, M., Karmakar, S., Debsarcar, A., Sen, P.K., Mukherjee, J.: Application of rural slaughterhouse waste as an organic fertilizer for pot cultivation of solanaceous vegetables in India. Int $\mathbf{J}$ Recycl. Org. Waste Agric. (2013). doi:10.1186/2251-7715-2-6

10. Ciesielczuk, T., Rosik-Dulewska, C., Wiśniewska, E.: Possibilities of coffee spent ground use as a slow action organo-mineral fertilizer. Ann. Set Environ. Protect. 17, 422-437 (2015)

11. Molnarova, M., Smelkova, M., Fargasova, A.: Assessment of the suitability of phytotoxkit plastic vertical containers compared with petri dishes for standard seedling growth tests. Bull Environ. Contam. Toxicol. (2014). doi:10.1007/s00128-013-1186-1
12. Kim, M.K., Min, H.G., Koo, N., Park, J., Lee, S.H., Bak, G.I., Kim, J.G.: The effectiveness of spent coffee grounds and its biochar on the amelioration of heavy metals-contaminated water and soil using chemical and biological assessments. J. Environ. Manage. (2014). doi:10.1016/j.jenvman.2014.07.001

13. Ballesteros, L.F., Teixeira, J.A., Mussatto S.I.: Chemical, functional, and structural properties of spent coffee grounds and coffee silverskin. Food Bioprocess. Technol. (2014). doi:10.1007/ s11947-014-1349-z

14. Poulsen, P.H.B., Magid, J., Luxhøi, J., de Neergaard, A.: Effects of fertilization with urban and agricultural organic wastes in a field trial - Waste imprint on soil microbial activity. Soil Biol. Biochem. (2013). doi:10.1016/j.soilbio.2012.02.031

15. Ciesielczuk, T., Rosik-Dulewska, Cz., Kochanowska, K.: The influence of biomass ash on the migration of heavy metals in the flooded soil profile - model experiment. Arch. Environ. Prot. (2014). doi:10.2478/aep-2014-0034

16. Demeyer, A., Voundi-Nkana, J.C., Verloo, M.G.: Characteristics of wood ash and influence on soil properties and nutrient uptake: an overview. Bioresour. Technol. 77, 287-295 (2001)

17. Mazur, Z., Radziemska, M., Tomaszewska, Z., Świątkowski, Ł.: Effect of sodium chloride salinization on the seed germination of selected vegetable plants. Sci. Rev. Eng. Environ. Sci. 62, 444453 (2013)

18. Colarieti, M.L., Toscano, G., Greco, G. Jr.: Toxicity attenuation of olive mill wastewater in soil slurries. Environ. Chem. Lett. (2006). doi:10.1007/s10311-006-0050-5

19. Saadi, I., Laor, Y., Raviv, M., Medina, S.: Land spreading of olive mill wastewater: effects on soil microbial activity and potential phytotoxicity. Chemosphere (2007). doi:10.1016/j. chemosphere.2006.05.019

20. Cesaro, A., Belgiorno, V., Guida, M.: Compost from organic solid waste: quality assessment and European regulations for its sustainable use. Resour. Conserv. Recycl. (2015). doi:10.1016/j. resconrec.2014.11.003

21. Oleszczuk, P.: The toxicity of composts from sewage sludges evaluated by the direct contact tests phytotoxkit and ostracodtoxkit. Waste Manage. (2008). doi:10.1016/j. wasman.2007.06.016 